\title{
Структура художественного конфликта в малой прозе В. Брюсова
}

\author{
Васильева Л.И., студентка, \\ Технический институт (филиал) \\ Северо-Восточного федерального университета, \\ 2. Нерюнгри \\ E-mail: monalyiza@mail.ru
}

\section{Научный руководитель: д.филол.н., профессор Осипова О.И.}

Символизм, характеризующийся дуализмом идеального и материального, противопоставлением рационального и иррационального, предстает еще как новый тип сознания в искусстве и категория мировоззрения. Основным признаком этого модернистского течения становится двоемирие, проявляющееся в антиномических отношениях между миром реальным и инобытием.

Идея двоемирия повлияла на структурные элементы формы и содержания литературного произведения, но одним из ее главных проявлений становится художественный конфликт, в котором она отразилась наиболее полно. И в творчестве одного из основоположников символизма - В. Брюсова - конфликт выражается в обобщенном и универсальном виде, реализованном в бинарной оппозиции двух миров.

Конфликт в произведении - центральная категория. Схема художественного произведения конструируется на столкновении, борьбе, антиномии. Многие исследователи в области теории литературы обращали внимание на феномен конфликта в творчестве различных писателей (М.М. Бахтин, М.Л. Гаспаров, Д.С. Лихачев, Ю.М. Лотман, Ю.Н. Тынянов) среди современных исследователей можно назвать Ю.Б. Борева, А.Г. Коваленко, А.Г. Погрибного и др. Новый методологический подход, согласно которому художественный конфликт рассматривается как «пучок антиномий», «поле антиномичной напряженности» (А.Г. Коваленко), а также включение в исследовательский аппарат понятия «антиномического вектора», определяющего выбор ценностных ориентиров автора (А.Г. Коваленко), позволяет поновому взглянуть на поэтику малой прозы В. Брюсова.

В научных трудах, посвященных малой прозе В. Брюсова наблюдаются пробелы, связанные с недостаточной разработанностью художественного конфликта конфликтная составляющая не привлекала внимания исследователей, тогда как «конфликт является также источником, или изначальным эстетическим импульсом процесса создания художественного произведения» [4, стр.11].

Художественное произведение, содержащее в себе ценную смысловую и идейную нагрузку и достойное изучения, является всегда поликонфликтным. В первую очередь для определения структуры конфликта необходимо выявить все антиномии на разных уровнях текста и определить их статус (основной конфликт или второстепенный), но при этом не забывая, что каждая антиномическая пара является элементом одного целого.

Следующий этап предполагает определение направления ценностного «вектора» антиномии, который является отражением приоритетных ценностных ориентаций автора. Вектор - это по сути направление от одной конфликтной стороны к другой, так 
в большинстве случаев он направлен от быта к бытию, от внешнего к внутреннему, от настоящего к прошлому или к будущему [5, стр. 8].

В конфликте находит отражение авторская позиция. Если автор субъективен по отношению к конфликту и его разрешаемости, то конфликт является валентным. В случае, когда автор отстраняется и изображает конфликт максимально объективно, он амбивалентен [5, стр. 9].

Целостный анализ конфликта невозможен без определения медиации или разрешения антиномии: «медиатором оппозиции может быть характер, в другом стиль, в третьем - образ-символ. Текст как бы «поглощает» антиномическую полярность, трансформирует ее в оппозицию иного, чаще всего, меньшего по масштабу уровня. Текст «растворяет» в себе антиномию, при этом «гасит» ее, рассеивает по всему пространству текста» [4, стр. 23].

Таким образом, конфликт - это «система всех антиномических отношений, сумма всех бинарных оппозиций на всех уровнях, взятых в наиболее интегрированном виде» [5, стр. 8]. Он является одной из важнейших структурных категорий художественного текста, по сути «текстообразующей» его особенностью и «текстопорождающей» компонентой художественного произведения. Это положение имеет прямое отношение и к циклам Брюсова, новеллы которого не просто пронизаны многообразными антиномическими «нитями», но целиком существуют в рамках многообразных пространственных, временных и этических антиномических координат.

Природу художественного конфликта в циклах «Земная ось» и «Ночи и дни» можно охарактеризовать как антиномическую конструкцию, имеющую сложную иерархическую структуру.

Причиной основного конфликта в цикле «Земная ось» (1907) служит неприятие героями действительности. Так, изначальную бинарную оппозицию составляет пара человек-среда. Внешний конфликт личности с окружающим миром переходит во внутренний: он переносится в сферу сознания и в этом переходе основную функцию играют мотивы тайны, зеркала, кажимости. Несовершенство мира реального толкает их на создание мира ирреального: герой в поисках свободы теряет связь с реальностью, попадая во власть видений, бреда, что приводит к помутнению сознания, или создает свой мир фантазий, где чувствует себя комфортно и живет по своим законам и правилам. Созданный с помощью воображения или фантазии мир - это место, где «человеческая душа освобождается от власти... от всех цепей, наложенных на нее наследственностью и воспитанием, от всех внешних влияний, обычно обусловливающих нашу волю: от страха перед судом, от боязни общественного мнения и т. д.» [1, стр. 20]. Например, главная героиня новеллы «В зеркале» предпочитает завораживающий мир зазеркалья: «у каждого зеркала есть свой отдельный мир, особенный. Поставьте на одно и то же место, одно за другим, два зеркала - и возникнут две разные вселенные» [1, стр. 36]. Для отражения характерологического (внутриличностного) конфликта автор часто использует прием двойничества. «Диссоциация» обусловлена сложностью человеческого сознания, оно делает сознание героя и субъектом и объектом познания («Теперь, когда я проснулся», «В зеркале», «Первая любовь»).

Антиномичными становятся лейтмотивы утраты героем границы между реальностью и ирреальностью и возвращения в реальный мир: происходит взаимопроникновение двух миров, что неизбежно приводит к катастрофе внешней или внутренней. Так, «земную ось» можно интерпретировать как невидимую грань 
перехода из мира реального в мир иной. Ни одному из героев так и не удается найти баланс между миром внутренним и внешним - тут автор реализует свою позицию о том, что постичь истину до конца невозможно и для человека это задача непосильная, поскольку между реальностью и фантазией, явью и сном нет чёткой границы.

Конфликт также формирует хронотоп произведения. В новеллах в рамках одной сюжетной ситуации совмещаются два времени-пространства и постоянная смена уровней хронотопа предстает как своеобразная игра с читателем, которая создает атмосферу напряженности и определяет пуант, но в итоге мотив тайны заставляет читателя задуматься, где кончается реальность и начинается инобытие. Антиномия двоемирия решается в условиях прошлого («В подземной тюрьме (По итальянской рукописи XVI века)», «В башне»), настоящего («Бемоль», «Сестры»), будущего времени («Республика Южного креста», «Земля»).

Схему развития конфликта в интегрированном виде можно представить следующим образом:

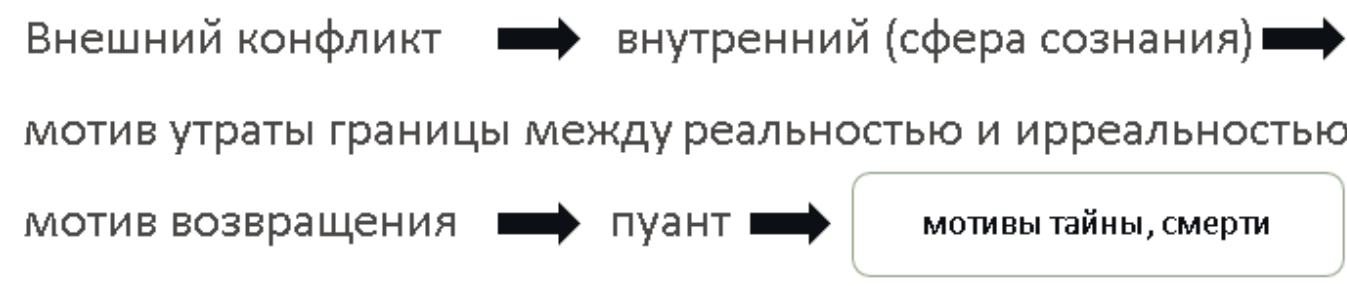

Рис. 1. Вектор и медиация конфликта в цикле «Земная ось»

«Земная ось» - книга, которая представляет собой глубокий и всесторонний анализ жизни и сущности человека. Основная антиномия служит для раскрытия (познания) и ограничения мира внутреннего и внешнего: тот, кому удастся провести невидимую ось между миром внутренним (миром для себя) и миром внешним (миром для других), постигнет тайны бытия, но в цикле ни один из героев не может разграничить мир этот и мир тот.

Цикл «Ночи и дни» (1913) композиционно состоит из 8 произведений: повести, пяти рассказов, эпизода «Ночное путешествие» и одноактной «психодрамы» «Путник». Обилие экзистенциальных мотивов актуализирует в произведении внутренний мир героя, а не окружающую среду, поэтому в этом цикле представлен только хронотоп современности.

В основе произведений лежит любовный конфликт, изображенный как «роковой поединок» между мужчиной и женщиной. Лейтмотив «рокового поединка» позволяет раскрыть в полной мере женскую и вместе с тем мужскую сущность. Но вопросы, которые поднимаются в цикле не ограничиваются сферой любви: «писатель показывает человека обобщённо, поскольку ему важен не какой-то определённый характер, а событие, бесповоротно перечёркивающее всё, что происходило с героем прежде, и (как и в новеллах первой книги), заставляющее его искать выход из «лабиринта» загадок и тайн» [3, стр. 196].

Здесь на современном Брюсову хронотопе решается проблема соотношения искусства и жизни через антиномию двоемирия. В повести «Последние страницы из дневника женщины» герои пытаются провести больше времени «вне ненавистной и нестерпимой стихии современности» [2, стр. 48]. Погружение в мир иной, является «каким-то слиянием яви и сна, чем-то, стоящим на границе действительности и мечты... то было нечто иное...» [2, стр.49]. 
Любовь в цикле предстает как чувство, испытав которое герои стремятся убежать от пошлой реальности и внести новый смысл в свою жизнь. Для достижения своих желаний они обращаются к миру искусства, пытаясь заменить существующее мироустройство. Бегство в мир иной оборачивается для всех героев трагедией: инобытие не может существовать в гармонии с реальностью.

Особняком стоит новелла-эпизод «Ночное путешествие», который является метатекстом ко всем произведениям цикла. Здесь конфликт двоемирия изображается, как в новеллах первого цикла: описывается «путешествие» героя на другую планету. Проводником его является дьявол. В рамках произведения сменяются два уровня хронотопа - реальности и ирреальности. Увиденное на чужой планете не удовлетворяет главного героя: «я думал, что ты поведешь меня во вселенные иного измерения, где что-то новое прибавится к мере всех предметов, или во вселенные иного времени, где кроме прошедшего, настоящего и будущего окажется нечто четвертое. А ты, во всей беспредельности бытия, не нашел ничего лучшего, как показать мне фейерверк, который можно точно воспроизвести синематографом, да блуд цветов - зрелище, от которого меня тошнит» [2, стр. 134]. В итоге он оказывается в привычных ему условиях, но проникновение другой реальности все-таки ощущается: «ничего не изменилось вокруг, но портьера перед окном была поднята, а в окне одно стекло разбито вдребезги» [2, стр. 135]. Так, автор оставляет вопрос открытым: было ли совершено «путешествие» или же это было плодом фантазии героя.

Вектор антиномии направлен в мир иной и схематически развитие конфликта можно представить следующим образом:

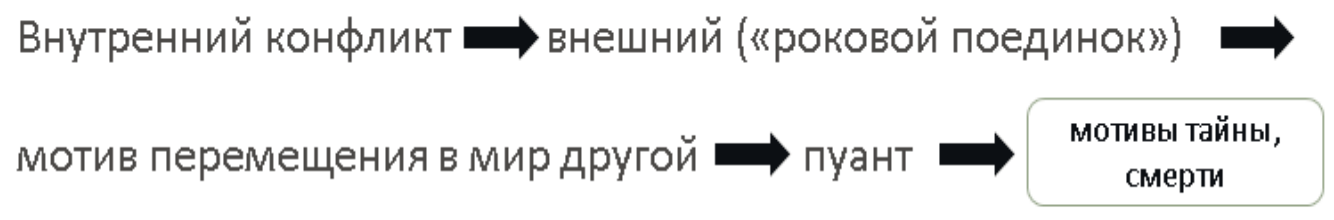

Рис. 2. Вектор и медиация конфликта в цикле «Ночи и дни»

В структурах конфликта, представленных в циклах В. Брюсова, наблюдаются точки пересечения, что говорит о парадигматическом развертывании конфликта, решающего одну проблему различными способами. Конфликт двоемирия разрабатывается на разных сюжетных линиях. В циклах можно провести параллели относительно развития основной антиномии. Так, источником конфликта является сознание героя - оно создатель мира иного. Следующий этап - взаимопроникновение двух миров, что неизбежно ведет к трагедии. И в итоге мотивы тайны или смерти во всех произведениях оставляют конфликт неразрешенным.

Список литературы:

1. Брюсов В.Я. Проза: собрание сочинений: в 3 т. Т.1 Рассказы и повести. / В.Я. Брюсов. - М.: Библиосфера, -1997. - 528 с.

2. Брюсов В. Я. Ночи и дни: Вторая книга рассказов и драматических сцен (19181912) / В. Я. Брюсов. - М.: Скорпион, - 1913. - 178 с.

3. Дубинина Л.А. Поэтика малой прозы В.Я. Брюсова 1900-1910-х годов: дисс. ...канд. филол. наук / Дубинина Любовь Анатольевна. - Харьков, 2015. - 226 с.

4. Коваленко А.Г. Художественный конфликт в русской литературе XX века (структура и поэтика художественного конфликта в русской литературе XX века). Пособие по спецкурсу. - М.: Изд-во РУДН. 2001.- 57 с. 
5. Коваленко А.Г. Антиномизм и бинарный архетип в структуре художественного конфликта / А.Г. Коваленко // Вестник РУДН, Литературоведение. Журналистика. 2003-2004. - № 7-8 - C.5-14.

\title{
Элементы волшебной сказки в рассказе А.П. Чехова «Белолобый»
}

\author{
Горохова Н.Д., студентка, \\ Северо-Восточный федеральный университет, \\ 2. Якутск \\ E-mail: nyurquyana.gorokhova@yandex.ru
}

\section{Научный руководитель: к.филол.н., доцент Ощепкова А.И.}

Антон Павлович Чехов вошел в историю детской русской литературы благодаря своим двум произведениям: «Каштанка» и «Белолобый». Из письма к издателю Г.И. Россолимо он писал: «То, что у меня, по-видимому, подходит для детей, — две сказки из собачьей жизни...» [4, стр. 19]. Такое определение многозначительно: тут и признание сказки как жанра, специально приспособленного детям, тут и ключ к разгадке авторского замысла. Ведь действительно, эти произведения напоминают сказки, у которых всегда счастливый конец. Рассказ «Белолобый» представляет собой образец сказочного жанра о животных, воспитывающие интерес и любовь к ним, демонстрирующие ценность таких чувств, как преданность и привязанность. В этой связи представляется интересным рассмотреть, каким образом сюжетная структура рассказа соответствует типологии сказочного повествования. Важно рассмотреть насколько четко прослеживаются элементы волшебной сказки, выявленных и описанных В.Я. Проппом, в рассказе А.П. Чехова.

Волшебную сказку Пропп трактует следующим образом: «рассказ, построенный на правильном чередовании приведенных функций в различных видах...» [2, стр. 91].

На основе обобщения различных фольклорных источников В.Я. Пропп сформулировал следующие четыре центральных положения, которые развиваются в «Морфологии...»: 1) «Постоянными, устойчивыми элементами сказки служат функции действующих лиц, независимо от того, кем и как они выполняются. Они образуют основные составные части сказки», 2) «Число функций, известных волшебной сказке, ограничено», 3) «Последовательность функций всегда одинакова...», 4) «Все волшебные сказки однотипны по своему строению, т.е. дают одинаковые функции» [2, стр. 22].

В.Я. Пропп к постоянным величинам относит тридцать одну функцию действующих лиц. Однако следует сказать, что не все функции присутствуют в сказках. Но последовательность остается всегда. Также устойчивы и семь действующих лиц: герой, антагонист (вредитель), даритель волшебных средств герою сказки, волшебный помощник, царевна или ее отец, отправитель, ложный герой, каждый из них имеет свой круг действий, выполняет одну или несколько функций.

В основу сюжета «Белолобый» положен рассказ о щенке, случайно оказавшегося в логове у волчихи. События развиваются очень увлекательно и динамично. Учитывая особенности детского восприятия, А.П. Чехов начинает повествование сразу, без 